Shumeiko 0. - Postgraduate Student of the Department of Philosophy of Law and Legal Logic of the National Academy of Internal Affairs, Kyiv, Ukraine

ORCID: https://orcid.org/0000-0003-3895-8372

\title{
Philosophical and Legal Analysis of the European Institution of Family in the Middle Ages
}

The purpose of the article is to review the historical development of the family institute in the Middle Ages. The main task of this work is to determine the relationship between the social and legal prerequisites for the formation of a family institution and the ideological foundations of this financial institution. Methodology. The pivotal methodological approach to the study is historical. The historical-legal method has allowed us to consider the origins and evolution of the family institute in the Middle Ages. Scientific novelty. The family acts as the basis for the organization of economic activity in society at this time. It is noted that the Christian ideology laid the foundation for the personalization of marital relations, contributed to overcoming the need for biological reproduction to the background. The main idea of the article is that marriage and family are universal forms of organization of relations between people, meeting their needs. It is reported that we (like other scientists) can highlights three great periods in the evolution of the family: 1) Period I traditional family, 2) Period II - newest family, 3) Period III - modern - or post newest family. One of the striking examples of the period of the newest family is the evolution of the institution of family in the Middle Ages, because of the spread of world religions, especially Christianity, strengthened the ideological bond that connected the family. The text gives valuable information on next: marriage from an economic institution became more and more a union of a man and a woman, based on love and emotional relations. The family became more and more focused on its internal life, and the role of intra-family relations grew. The main functions of the family are providing the needs of marriage, motherhood and the upbringing of children. Thus, it is reported that the family in Middle Ages is considered to be based on marriage or blood-related ties a small social group whose members are related to the commonality of life, mutual moral responsibility, emotional and spiritual affinity. The following conclusions are drawn that 1) in the Middle Ages and during the period of early New age concept of the "family" designated general community of dependent on the primary host people and all the rest of the household, because the pre-industrial social structure was based on the family menage; 2) the family acted as a productive, reproductive and consumer unit, and was the basis for the organization of work, while the form of life of the "whole house" never covered the entire population; 3) at the same time, the Christian ideology lays the foundations for personalization and individualization of family life, forming it on the basis of love and harmony of marital relations; 4) in recent times, family problems are very often viewed from the perspective of the relationship between him and her.

Keywords: family; institution of family; Middle Ages; society; social philosophy; philosophy of law; Christian ideology; marital relations.

\section{Introduction}

Marriage and family are universal forms of organization of relations between people, meeting their needs. This universality is largely achieved on the basis of multi-variation, which is observed in both historical and contemporary contexts. The history of family formation largely helps to understand the problems faced by the institution of family today.

The pivotal methodological approach to the study is historical. The historical-legal method has allowed us to consider the origins and evolution of the family institute in the Middle Ages.

Historian Elisabeth Roudinesco highlights three great periods in the evolution of the family:

- Period I - traditional family, serving first and foremost to secure the transfer of property inheritance. Marriages are arranged by parents who do not take into account the sexual and affective life of the future spouse, which is usually arranged at an early age. From this angle, the family cell is based on an inviolable world order, which is entirely subordinated to the authority of the father, and this is a true transfer of the power of divine law;
- Period II - newest family becomes a repository of affective logic, the model of which is approved from the end of the XIII - to the beginning of the XX century. Based on romantic love, the family by marriage legitimizes the commonality of feelings and carnal desires, and approves the division of labour between the spouses, transforming the child on the subject, the education of which should be provided by the nation. Giving power is henceforth the goal of a permanent separation between the state and parents, on the one hand, between fathers and mothers, on the other;

- Period III - modern - or post newest family, which has been approved since the 1960's, connects the relative term of two individuals who seek an intimate relationship or sexual flourishing. The affiliation of power is becoming now a more problematic measure of how the number of divorces and shuffling of families increases (Rudynesko, 2004, p. 21-22).

Among the scholars who researched the institution of family were: L. Morgan, F. Engels, I. Kon, S. Golod, V.Rozanov, E. Roudinesco, A. Kudinova, S. Cherepanova, Elisabeth van Houts. The study of the formation of the history of the incipience of the European Institution of family in the 
Middle Ages is considered in the works of A. Guliga, Jacques Le Goff, Georges Duby, S. Averintsev. We must note that the study of the family of the Middle Ages was not described in any specialized scientific research. In addition, the problem of the formation of the institution of family in accordance with modern realities requires a critical rethinking of the existing historical heritage.

\section{The purpose and objectives of the study}

The purpose of this scientific exploration is the historical evolution of the institution of family in the Middle Ages. The main task of this work is to determine the relationship between the social and legal prerequisites for the formation of the institution of family and the ideological foundations of this financial institution.

\section{Presentation of the main material}

One of the striking examples of the period of the newest family is the evolution of the institution of family in the Middle Ages, because of the spread of world religions, especially Christianity, strengthened the ideological bond that connected the family. Marriage from an economic institution became more and more a union of a man and a woman, based on love and emotional relations. The family became more and more focused on its internal life, and the role of intra-family relations grew. The main functions of the family are providing the needs of marriage, motherhood and the upbringing of children. Thus, the family is considered to be based on marriage or blood-related ties a small social group whose members are related to the commonality of life, mutual moral responsibility, emotional and spiritual affinity.

The medieval society had a strict hierarchy, considering it to be given by God: "Let every man obey the supreme authority, as there is no power other than God, and the existing powers are established from God» (Rom. 13, 1). This hierarchy was not in doubt.

A man of the Middle Ages grows with the community, which is necessary for him in the material and the psychological sense in times of wars and emergencies, hunger and migration of peoples. As P. Dincelbaher writes «relationship in the medieval society takes place between the person and the institution» (Dintselbakher, 2004, p. 58).

The family (familia) in the Middle Ages acts as a community-prototype of all other group formations, and blood ties are often replaced by a canon law (Dintselbakher, 2004, p. 61). Probably till the critical (according Le Goff) for Western Europe 1200 year the family (familia) will be only a constant and stable unit in the formation of a social hierarchy and society in general, a reliable protection from «the darkness of the afterlife» and «unknown».

Outstanding researcher of the Middle Ages Le Goff says: «... in the field of sexual life Christianity is dependent both from the inheritance and borrowings (Jewish, Greek-Latin, gnostic) and from the trends of the time. It appears as a member of a large movement of economic, social and ideological structures of the first four centuries, named Christian, where it is at the same time - as it often happens in history - the consequence and the engine. But its role was decisive" (Hoff, 2007, p. 130).

Referring to $P$. Veyne, the historian writes that Christianity has given a transcendental foundation, confirmed simultaneously by the theologians and the Bible. It has transformed the tendency of the minority to «normal» behavior of the majority, in any case, among the ruling classes of the aristocracy and the townspeople; gave new behavior a new conceptual and categorical definition, and imposed strict social and ideological control that the Church and secular authorities put into service. Christianity offered an exemplary society, which, in its ideal form, introduced a new sexual model - monasticism. This aspect of Christian ideology is perfectly analyzed in the work of Russian philosopher of the early twentieth century V. Rozanov «People of the Moonlight» (Rozanov, 1990).

Le Goff adds: "To the reasons, which could push the Romans-pagans to chastity, to limit sex life by family frame, condemnation of miscarriages, disapproval of "love addiction", discrediting of bisexuality, the Christians added another urged motif: the approach of the end of the world, which requires impeccability» (Hoff, 2007, p. 131).

The French researcher describes three notions through which the unification of the condemnation of sexual intercourse occurs:

1. the notion of seduction (fornication) that appears in the New Testament and will be sanctified, especially since the end of the 13th century, by the sixth God's commandment: "No adultery», which would mean all illegal sexual acts (also in a married couple);

2. the concept of lust (concupiscence), which is often found at Church Fathers and which stands at the "sources of sexual life»;

3. the concept of fornication (luxure), which covered all the bodily sins, when the system of sins has evolved from the V-XII century (Hoff, 2007, p. 131-132).

In the Gospel of the New Testament monogamous and inextricable marriages are approved. Hence - the conviction of marital betrayal (Matt. 5:32) and divorce, which equates to marital treason (Matt. 19: 2-12; Mp. 10:2-12; L. 16:18). But the «exemplary» figures of the Middle Ages did not 
legitimize the sexual life in their behavior: Mary marries a virgin and Christ is single.

As S. Averintsev says, Christian marriage is a sacrament, it is not a subject to dissolution, «the Union of unconditional forgiveness and boundless confidence is concluded only forever, because faith and loyalty, worthy of this name, do not know the end, because the Covenant of God is an eternal Covenant» (Averintsev, 2006, p. 814).

Modern Greek philosopher Christos Yannaras said that perhaps for the first time in the history of mankind just in the Christian doctrine marriage is exempt from the ontological necessity of biological reproduction and gaining the image of the Church, implementation of the trinitarian mode of existence (Yannaras, 2003, p. 52).

However, the realities of intimate life in the Middle Ages were not at all optimistic. As the French historian Georges Duby notes, the traditions of the Middle Ages erected a barrier between the male and female world, generating misunderstanding and mistrust on both sides. At the age of seven, boys were taken away from their mothers, and their later life was predominantly among men. Such practice, says the historian, not only contributed to the development of homosexual inclinations, created not only the image of not available comforter, but to the forming of frightening idea of what can women do in their circle, attributing them a secret and dangerous power.

As the researcher notes, from the turn of the XIII-XIII centuries, the general press freed the person from the bond of collective forms of life. The curiosity, the cult of the "beautiful lady», greatly weakened violence and rudeness in the sexual behavior of men and the matrimonial policy of the generations. Men began to understand that a woman is not only the body that must first be conquered by her heart, but also by her consent, which must be recognized as a woman of special virtues. The commandments of the love code corresponded to that preached by the Church, trying to prove that women should have equal rights with men not only on the marriage bed, but also in matters of consent to marry (Diubi, 1990, p. 90-96].

However, we must note that in feudal society «family relations have a real character of personal rights». That is why in the Middle Ages there was a law of Majorat, according to which the law of family property is completely passed to the elder by birth from the heirs, and the remaining family members were denied the right of inheritance. Incidentally, the effect of this law has led France to a corresponding period on the brink of extinction. Usually the family tried to marry one, most often the eldest son. The rest remained mostly single, who met their sexual needs with prostitutes, maids and illegitimate people. The role structure of the patriarchal family was rigid and hierarchical, based on the principle of seniority.

E. R. Wolf points out that in the homogeneous society (antique and medieval society) the line of affinity for sure and definitely sets the place of man in society, however, it emphasizes that the laws of succession are connected "with the need for a certain discrimination of the rights of the individual», which is most clearly manifested in relation to children (Vulf, 2004, p. 105).

This epoch in its ideological directions was based on the texts of the sacred scripture. Biblical teachings were the source material for the philosophical comprehension of Christian philosophers. Thus, Aurelius Augustinus was a passionate supporter of the ideas of the Apostle Paul, he developed his understanding of love, marriage and family within the study of the problems of the formation and development of the human personality. First of all, Augustine highlights three forms of love the love of man to God, love for the neighbor and the love of God to man. The true form for the thinker is the first form, because man loves everything in the name of God, loves love for God itself. Love is a feeling and a definition that is worthless only to God and to man it has nothing to do.

The philosopher supports the position of the New Testament concerning interethnic relations, acting as a passionate supporter of renunciation of marriage and preservation of chastity. In his treatise «The City of God» he foresaw two opposite types of human community: statehood based on «the love to yourself that is brought to the disregard of God» and "The City of God» - a spiritual community that is based on the love of God and scorn to themselves. Ideal for the philosopher is the "City of God", where there is no place for love, marriage, families that were seen as a sin against nature.

The philosopher opposes spiritual love, having transcendental aspirations, to the bodily (carnal) love the lust - that is love directed at the real world for its own sake. He is convinced that the painful passion of lust in married life is not love, as necessity, and the process of procreation is the boon of marriage and only that's why «married life must be praised, because it makes some benefit from the blemish and lust» (Avgustin Avreliy, 1990, p. 481).

The third form of love, according to Augustinus, is the love of God for creation. God not only loves, he himself is love, the sacrament of which is in the doctrine of triuneism. In this aspect, love is immensely and inaccessible to man, as stated in the Bible: "God is love, and one who is in love, is in God, and God is in him» (1 John 4: 16).

St. Augustine first linked the original sin and sex through lust; he claims that the lust is the bearer of 
original sin. Starting from Adam and Eve, original sin is transmitted to human through sexual intercourse. This concept in the twelfth century was recognized by all except Abelard and his students. As Le Goff notes: «Due to its vulgarization by most preachers, confessors and authors of the moral treatises, the displacement of meaning will lead to the assimilation of original $\sin$ to sexual sin. Mankind will be conceived in sin, and every connection is sinful - by the power of lust, which is revealed in it» (Hoff, 2007, p. 134).

The ideological opponent of Augustine - the monk Pelagius (360-418 years) was known for his morality. (At the initiative of Augustine at the III Ecumenical Council in 431 the Pelagius doctrine was condemned as a heresy.) In 414 the noble roman Juliane asked him to give a spiritual instruction to her daughter, and this instruction was "The Epistle to Demetrius», the only work that was completely preserved. The main idea of the "Epistle» is to show Demetrius, who wished to dedicate her life to God, renouncing her marriage, the correctness of her choice and the dignity of such life. Pelagius illustrates his teaching that a person in the power of free will is capable completely independently, without the participation of the Church, to do good, avoid evil and in this way achieve the moral ideal, happiness, salvation.

Reflecting on what the Bible allows marriages, he emphasizes: "The permission of marriage makes the honor to virginity», moreover, «... the reward for virginity is promised to both sexes». Thinker explains the girl that «of all the vices, that lured people, there are two - gluttony and voluptuousness» and only "having loved virtues, we despise carnal passions (Pelagiy, 1986, p. 601).

One of the representatives of the Church Fathers was John Chrysostom, who argued that the magnificence of love is that one who loves and one who is loved is already one person. Marital love is the strongest type of love: «marriage is the sacrament of love, because marriage is a mystery already because it exceeds the limits of our minds, because in it two become one». (1 Cor. 7;39,40).

Thomas Aquinas, aiming to strengthen the faith by the mind, combines the teachings of Aristotle with Christian dogmas. In solving the problem of marriage and family relations, the philosopher takes as the basis the structural link of the relationship built by Aristotle - family, settlement, state. Social life is a continuation of family life, and the bonds of marriage are inseparable, explaining this by the necessity of compulsory participation of both parents in the education of children. All forms of sexual activity Aquinas considers as heresy and offense, sexual arousal is unnatural. The philosopher considers homosexuality, «unnatural» poses in intimate relationships and contraceptives as the most serious sin against nature.

The echo of the Christianized understanding of marriage we can hear today.

So, as noted by modern scholars I. Andreyeva and A. Guliga: «For the harmonious life of the family a special spirituality and awareness of the holiness of marriage and paternity are required. Religion for many centuries brought up this spirituality. All that serves as the education of ideas about the responsibility of those who take marriage, about the sanctity of family responsibilities is a boon. But the blessing for the family is also the freedom to choose the form of consecration of a marriage union. A secular or church form of marriage does not make a happy family. Rite is the action of one act, and family happiness is the whole life» (Gulyga, \& Andreeva, 1991, p. 515).

It is important to note that the complex relationship between East and West of the Roman Empire also led to differences in opinions on the functioning of the institution of family in Byzantium and Rome.

\section{Scientific novelty}

The family acts as the basis for the organization of economic activity in society at this time. The Christian ideology laid the foundation for the personalization of marital relations, contributed to overcoming the need for biological reproduction to the background. The marriage and family are universal forms of organization of relations between people, meeting their needs.

\section{Conclusions}

Therefore, we have to note that in the Middle Ages and during the period of early New age concept of the "family» designated general community of dependent on the primary host people and all the rest of the household, because the preindustrial social structure was based on the family menage. The family acted as a productive, reproductive and consumer unit, and was the basis for the organization of work, while the form of life of the "whole house» never covered the entire population (Houts, 2019, p. 255-260). At the same time, the Christian ideology lays the foundations for personalization and individualization of family life, forming it on the basis of love and harmony of marital relations. In recent times, family problems are very often viewed from the perspective of the relationship between him and her (Lawson, Sun, \& McHale, 2019) and mainly in the problem vein (Carter, 2018; Morgan, 2019). 


\section{REFERENCES}

Averintsev, S. (2006). Brak i semia [Marriage and family]. N.P. Averintseva, K.B. Sigov (Eds.). Kiev: DUKh i LITERA [in Russian].

Avgustin Avreliy. (1990). O supruznestve i pokhoti [About matrimony and lust]. Filosofiia liubvi, Philosophy of love. (Vols. 1-2). Moscow; Politizdat [in Russian].

Carter, Ju. (2018). Women (Not) Troubling "the Family": Exploring Women's Narratives of Gendered Family Practices. Journal of Family Issues, November 2. 0192513X1880975. doi: https://doi.org/10.1177/0192513X18809752.

Dintselbakher, D. (Eds.). (2004). Istoriia yevropeiskoi mentalnosti [History of the European mentality]. (V. Kamianets, Trans). Lviv: Litopys [in Ukrainina].

Diubi, ZN. (1990). Kurtuaznaia liubov i peremeny v poloznenii znenshchin vo Frantsii XII v. [Courteous love and changes in the status of women in France of the $12^{\text {th }}$ century]. Moscow: Odissey [in Russian].

Elisabeth, V.H. (2019). Conclusion. Married Life in the Middle Ages, 900-1300. doi: https://doi.org/10.1093/oso/9780198798897.003.0009.

Forde, S. (2019). Introducing the Encyclopedia of the Global Middle Ages. Bloomsbury Encyclopedia of the Global Middle Ages. doi: https://doi.org/10.5040/9781350990005-0001.

Gulyga, A.V., \& Andreeva, I.S. (1991). Brak i semia segodnia [Marriage and family today]. (Vol. 3). Moscow: Politizdat [in Russian].

Hoff, Zh.L. (2007). Serednovicpna umava [Medieval imagination]. (Ya. Kravets, Trans). Lviv: Litopys [in Ukrainian].

Houts, V.E. (2019). Introduction. Married Life in the Middle Ages, 900-1300. doi: https://doi.org/10.1093/oso/9780198798897.003.0010.

Lawson, K.M., Sun, X., McHale, S.M. (2019). Family-friendly for her, longer hours for him: Actor-partner model linking work-family environment to work-family interference. Journal of Family Psychology. 14 Feb 2019. 0192513X1984879. doi: https://doi.org/10.1037/fam0000506.

Morgan, D.H.J. (2019). Family Troubles, Troubling Families, and Family Practices. Journal of Family Issues. May 9 , 2019. 0192513X1984879. doi: https://doi.org/10.1177/0192513×19848799.

Pelagiy. (1986). Poslanie k Demetriade [Epistle to Demetrides]. Filosofskie proizvedeniia, Philosophical Works. Moscow: Nauka [in Russian].

Rowley, T. (2019). The church in the later Middle Ages. The High Middle Ages 1200-1550. London: Routledge. doi: https://doi.org/10.4324/9780429059414-8.

Rowley, T. (2019). The high Middle Ages. The High Middle Ages 1200-1550. London: Routledge. doi: https://doi.org/10.4324/9780429059414-1.

Rowley, T. (2019). Villages in the late Middle Ages. The High Middle Ages 1200-1550. London: Routledge. doi: https://doi.org/10.4324/9780429059414-3.

Rozanov, V.V. (1990). Liudi lunnogo sveta: metafizika khristianstva [People of the moonlight: metaphysics of Christianity]. Moscow: Druznba narodov [in Russian].

Rudynesko, E. (2004). Rozladnana simia [Upset family]. (Trans). Kyiv: Nika-Tsentr [in Ukrainian].

Vulf, E.R. (2004). Yevropa i narody bez istoriï [Europe and nations without history]. (I. Poshyvailo, Trans). Kyiv: KM Akademiia [in Ukrainian].

Yannaras, Kh.Ch. (2003). Svoboda etosu [Ethos freedom]. (Trans). Kyiv: Dukh i Litera [in Ukrainian].

Стаття надійшла до редколегії 06.02.2019

Шумейко О. В. - аспірант кафедри фрілософії права та юридичної логіки Національної академії внутрішніх справ, м. Київ

ORCID: https://orcid.org/0000-0003-3895-8372

\section{Філософсько-правовий аналіз європейської інституції сім'ї в епоху Середньовіччя}

Метою статті є дослідження історичного розвитку інституту сімї в середні віки. Основним завданням $\epsilon$ визначення взаємозв'язку соціально-правових передумов фрормування інституту сімї та ідеологічних засад цієї фрінансової інституції. Методологія. Стрижневим методологічним підходом у дослідженні є історичний підхід. Завдяки історико-правовому методу було розглянуто витоки, еволюцію та підгрунтя нормативного регулювання інституту сім'ї в середні віки. Наукова новизна. Сім'я є підгрунтям для організації економічної діяльності в суспільстві в цей час. Християнська ідеологія заклала підгрунтя персоналізації шлюбних відносин, а також побічно сприяла подоланню необхідності біологічного розмноження. Основна ідея статті полягає в тому, що шлюб і сім'я є універсальними фрормами організації відносин між людьми та задоволення їхніх потреб. Грунтуючись на висновках провідних істориків інституту сімї, можна виокремити три значні періоди в 
розвитку родини: 1) період I - традиційна сім'я; 2) період II - новітня сім'я; 3) період III - сучасна або «постсучасна» сім'я. Одним із яскравих прикладів періоду новітньої сімї є еволюція інституту сімї в середні віки, оскільки поширення світових релігій, зокрема християнства, зміцнило ідеологічні зв'язки, що пов'язували родину. Шлюб, який спочатку був економічним інститутом, стає союзом чоловіка та жінки, що грунтується на любові й емоційних стосунках. Сім'я фрокусується на своєму внутрішньому житті, а важливість сімейних відносин збільшується. Основними фрункціями сімї є забезпечення потреб шлюбу, материнства та виховання dimeй. У статmі зазначено, що сім'єю в середні віки вважали заснованою на шлюбі або кровних зв'язках невелику соціальну групу, членів якої пов'язують спільне життя, взаємна моральна відповідальність, емоційна та духовна близькість. Висновки: 1) в середні віки та в період раннього Нового часу поняття "сім'я» позначало спільноту, залежну від головних приймаючих людей та інших членів домашнього господарства, оскільки доіндустріальну соціальну структуру було засновано на сімейному управлінні; 2) сім'я діяла як продуктивна, репродуктивна та споживча одиниця і була підгрунтям для організації праці, а форма життя «загального дому» ніколи не охоплювала все населення; 3) водночас християнська ідеологія закладає підгрунтя персоналізації та індивідуалізації сімейного життя, формуючи його на підставі любові та гармонії подружніх відносин; 4) останнім часом сімейні питання часто розглядають з позицій відносин між «ним» $i$ «нею», а також у проблемному аспекті.

Ключові слова: сім'я; інститут сім'ї; Середньовіччя; суспільство; соціальна фрілософія; фрілософрія права; християнська ідеологія; шлюбні відносини. 